\title{
Assay of gentamicin in cerebrospinal fluid
}

\author{
SUSAN DEACON \\ From the School of Pathology, Middlesex Hospital Medical School, London WIP 7LD
}

SYNOPSIS A comparison of standard curves obtained from a conventional plate diffusion assay method revealed significant differences when gentamicin standards were made up in different media. Standards made up in distilled water resulted in a curve which differed from that of standards made up in pooled human cerebrospinal fluid by a factor of up to 4 . When the assay medium was supplemented with $0.5 \%$ sodium chloride, the difference between the two standard curves was reduced to a factor of about $1 \cdot 5$. The curve obtained from standards made up in $150 \mathrm{mM}$ sodium chloride/ $4.5 \mathrm{mM}$ calcium chloride correlated well with that from standards made up in cerebrospinal fluid. There was no evidence of gentamicin being bound to protein in the cerebrospinal fluid.

Over $50 \%$ of the instances of meningitis in neonates are caused by Gram-negative enteric bacilli (Mathies et al, 1971). Gentamicin, being effective against these organisms, is a useful agent in the treatment of meningitis in the newborn.

Systemic administration of gentamicin does not give rise to adequate therapeutic levels in the cerebrospinal fluid. Riff and Jackson (1971) could not detect measurable levels in the CSF after intramuscular injection unless the serum level exceeded $4 \mathrm{mg} / \mathrm{l}$. McCracken et al (1971) reported a mean CSF gentamicin level of $1.2 \mathrm{mg} / \mathrm{l}$ (range $0 \cdot 2-2.9$ ) after intramuscular administration of $1 \cdot 5-2.5 \mathrm{mg} / \mathrm{kg}$. The same authors measured $2.6 \mathrm{mg}$ gentamicin $/ 1$ (range 2.5-2.7) in CSF 24 hours after an intrathecal dose of $0.5 \mathrm{mg}$, and $15.8 \mathrm{mg} / \mathrm{l}$ (range 4.3-60) after an intraventricular dose of $0 \cdot 5-1 \mathrm{mg}$. CSF levels of gentamicin up to $7 \mathrm{mg} / \mathrm{l}$ were obtained by Newman and Holt (1967) after $1-2 \mathrm{mg} / \mathrm{kg}$ per day intramuscularly and $0 \cdot 2-1 \mathrm{mg} /$ day intraventricularly.

It is well documented that the action of gentamicin is particularly susceptible to changes in the salt concentration of the medium (Rubenis et al, 1963; Schoutens and Yourassowsky, 1972). When it is necessary to assay the drug in body fluids this is usually done against reference standards which are made up in the same fluid in order to minimize any discrepancies due to variation in the constituents of the medium. However, this principle appears to have been neglected in assays of gentamicin in CSF, probably due, at least in part, to the fact that pooled human CSF is not readily available in many laboratories.
Reported levels of gentamicin in the CSF are often the result of assays against reference standards made up in water (Newman and Holt, 1967). In other cases the assay method is not described in sufficient detail, and this applies particularly to assays performed by a reference laboratory.

The purpose of this work was to show the extent of variation in results from standards made up in different media and to test the possibility of using a 'synthetic' substitute for pooled human CSF.

\section{Material and methods}

\section{PLATE DIFFUSION ASSAY}

Klebsiella edwardsii (NCTC 10896) was used as the test organism. Overnight cultures were grown in Todd Hewitt broth (Oxoid). Bacto antibiotic medium 11 (Difco) was used as the assay medium. This was supplemented where appropriate with $0.5 \%$ sodium chloride. Fifty millilitre volumes of assay medium were dispensed into $13.5 \mathrm{~cm}$ diameter plastic Petri dishes. Each plate was surface-seeded with approximately $4 \times 10^{6}$ organisms. Twelve wells, $9 \mathrm{~mm}$ in diameter, were cut in each plate. Gentamicin sulphate (Genticin Injectable, Nicholas Laboratories) standards were prepared at concentrations of $1 \cdot 25,2 \cdot 5,5,10$, and $20 \mathrm{mg}$ of gentamicin base/litre; $0.15 \mathrm{ml}$ of standard was added to each well. Zone sizes were measured after 5-18 hours' incubation to the nearest $0.5 \mathrm{~mm}$.

SOURCE OF CEREBROSPINAL FLUID CSF was pooled from specimens obtained from patients in the hospital. Before use it was tested for 
sterility and checked to ensure that no antibacterial agents were present.

PROTEIN BINDING ASSAY

The radioactive gentamicin used in protein-binding experiments was methyl-14 $\mathrm{C}$-gentamicin sulphate having an activity of $0.44 \mathrm{mCi} / 1$ and a specific activity of $0.4 \mathrm{Ci} / \mathrm{M}$ of free base. Radioactive samples were added to $8 \mathrm{ml}$ of $0.3 \%$ PPO/0.01\% POPOP/ toluene:ethanol $(5: 1)$ and counted in an Intertechnique model SL30 scintillation spectrometer.

Protein was estimated according to the method of Warburg and Christian (1942).

\section{Results}

Curves were obtained from standards made up in distilled water, pooled human CSF, $159 \mathrm{mM}$ sodium chloride, and $150 \mathrm{mM}$ sodium chloride $/ 4.5 \mathrm{mM}$ calcium chloride. Each standard was measured in triplicate. Figure 1 shows the results obtained using assay medium with no added salt. The resultant curve from standards made up in distilled water differs from the curve from standards in pooled CSF by a factor of 4 . Standards made up in $150 \mathrm{mM}$ $\mathrm{NaCl} / 4.5 \mathrm{mM} \mathrm{CaCl}_{2}$ give a curve which correlates well with the CSF curve. The curve obtained from standards in $159 \mathrm{mM} \mathrm{NaCl}$ differs from the distilled water curve by a factor of 2 .

Figure 2 shows the results obtained by the same

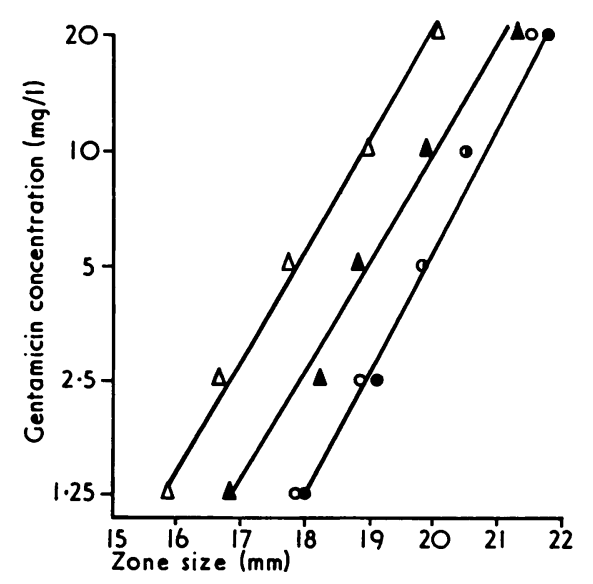

Fig 1 Standard curves for gentamicin obtained by a plate diffusion method using normal medium. Standards made up in

$\triangle \longrightarrow \triangle$ distilled water;

$\triangle \longrightarrow 159 \mathrm{mM} \mathrm{NaCl}$;

○- $150 \mathrm{mM} \mathrm{NaCl} / 4 \cdot 5 \mathrm{mM} \mathrm{CaCl}_{2}$;

- pooled human CSF.

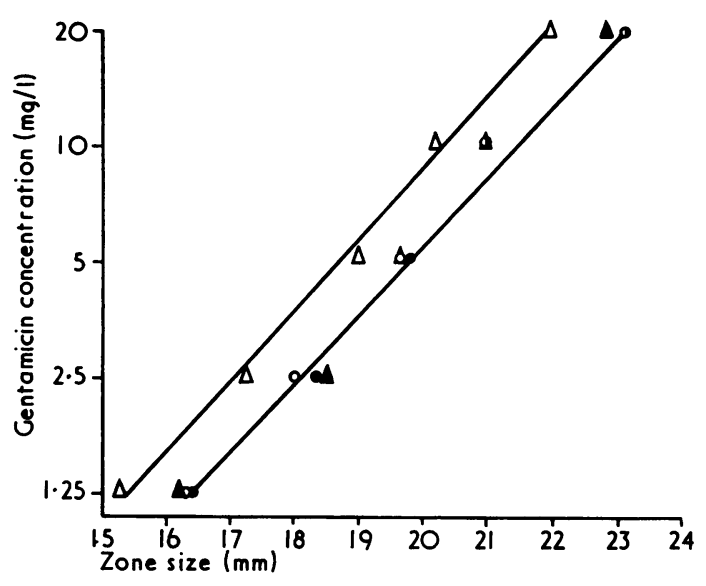

Fig 2 Standard curves for gentamicin obtained by a plate diffusion method using medium supplemented with $0.5 \% \mathrm{NaCl}$. Key as for fig 1 .

procedure as above except that the assay medium was supplemented with $0.5 \% \mathrm{NaCl}$. The difference in the curves from standards made up in water and in CSF is reduced to a factor of about $1 \cdot 5$. Both the curves from standards made up in $159 \mathrm{mM} \mathrm{NaCl}$ and in $150 \mathrm{mM} \mathrm{NaCl} / 4.5 \mathrm{mM} \mathrm{CaCl}_{2}$ correlate well with the CSF curve.

Results are shown for a single experiment but this was repeated four times. In the unsupplemented medium the CSF curve always differed from the distilled water curve by a factor greater than 3 . When the medium was supplemented with $0.5 \% \mathrm{NaCl}$ the difference always exceeded a factor of $1 \cdot 3$. These results were still reproducible when different batches of pooled CSF were used.

To test for protein binding $0.2 \mathrm{ml}$ of ${ }^{14} \mathrm{C}$-gentamicin was added to $0.8 \mathrm{ml}$ pooled human CSF to give a final concentration of $100 \mathrm{mg}$ free base/l. $0.2 \mathrm{ml}$ of ${ }^{14} \mathrm{C}$-gentamicin was also added to $0.8 \mathrm{ml}$ of $150 \mathrm{mM} \mathrm{NaCl} / 4.5 \mathrm{mM} \mathrm{CaCl} 2$ as a control. The samples were incubated for four hours at $37^{\circ} \mathrm{C}$ and

\begin{tabular}{llll}
\hline & $\begin{array}{l}\text { Total } \\
\text { Radioactivity } \\
\text { in DPM }\end{array}$ & $\begin{array}{l}\text { Radioactivity } \\
\text { in DPM } \\
\text { associated with } \\
\text { TCA Precipitate }\end{array}$ & $\begin{array}{l}\% \text { Activity } \\
\text { associated with } \\
\text { TCA Precipitate }\end{array}$ \\
\hline Test & $2.5 \times 10^{5}$ & 80 & 0.03 \\
Control & $2.6 \times 10^{6}$ & 101 & 0.04 \\
\hline
\end{tabular}

Table Distribution of ${ }^{14} \mathrm{C}$-gentamicin in the CSF

DPM = disintegrations per minute.

TCA = trichloroacetic acid. 
then added to an equal volume of $10 \%$ trichloroacetic acid. After centrifugation a sample was taken from the supernatant for counting and the precipitate was collected on to a $0.45 \mu$ pore size membrane filter and counted. The results are shown in the table.

The protein content of the CSF was estimated at $890 \mathrm{mg} / 1$.

\section{Discussion}

These results further emphasize theneed for standardization in antibiotic assays. Gentamicin levels reported using reference standards made up in water may be four times as high as the actual levels. Thus, a level which appears to be above the MIC for the infecting organism may well be subtherapeutic.

To date there have been no reports of toxic effects due to intrathecal or intraventricular administration of gentamicin. However, since a large number of cases described have involved neonates, there probably has not been sufficient follow-up completely to rule out this possiblity. It is also important therefore that assays are carried out accurately to ensure that potentially toxic levels are not reached. A level reported as being safe by one assay method could be toxic when assayed by a different method.

The salt solutions were prepared to correspond with the ionic strength of CSF. In salt-free medium the curves obtained from standards made up in 150 $\mathrm{mM} \mathrm{NaCl} / 4.5 \mathrm{CaCl}_{2}$ and $159 \mathrm{mM} \mathrm{NaCl}$ differed despite these solutions having the same ionic strength. This supports the theory that the effect of divalent cations such as $\mathrm{Mg}^{2+}$ and $\mathrm{Ca}^{2+}$ on the action of gentamicin is not solely related to their influence on the ionic strength of the medium (Gilbert et al, 1971). It is not certain why this effect of calcium ions is not apparent when the medium is supplemented with $0.5 \% \mathrm{NaCl}$.

There is also an increase in the range of zone diameters in the presence of $0.5 \% \mathrm{NaCl}$, and $\mathrm{I}$ have discussed this elsewhere (Deacon, 1976).
There was no association of gentamicin with CSF proteins in the specimen tested, which at $890 \mathrm{mg}$ protein/l had a protein concentration considerably higher than normal. However, in bacterial meningitis the protein content of the CSF may increase to $10 \mathrm{~g}$ or more per litre and it is not known whether such high levels would affect protein-binding of the drug.

It is clear from these results that gentamicin in CSF should not be assayed against reference standards made up in water. If pooled CSF is not available then $150 \mathrm{mM} \mathrm{NaCl} / 4.5 \mathrm{mM} \mathrm{CaCl} 2$ would seem to be an adequate substitute.

I am grateful to Dr R. E. M. Thompson for helpful advice in the preparation of this paper and to Miss Susan Lockwood for typing the manuscript.

The radioactive gentamicin was a gift from Nicholas Laboratories.

\section{References}

Deacon, S. (1976). Factors affecting the assay of gentamicin by the plate diffusion method. J. clin. Path., 29, 54-57.

Gilbert, D. N., Kutscher, E., Ireland, P., Barnett, J. A., and Sanford, J. P. (1971). Effect of the concentrations of magnesium and calcium on the in-vitro susceptibility of Pseudomonas aeruginosa to gentamicin. J. infect. Dis., 124, (suppl.), 37-45.

McCracken, G. H., Jr., Chrane, D. F., and Thomas, M. L. (1971). Pharmacologic evaluation of gentamicin in newborn infants. J. infect. Dis., 124, (suppl.), 214-223.

Mathies, A. W., Jr., Lavetter, A., Leedom, J. M., Ivler, D., and Wehrle, P. F. (1971). Gentamicin in the treatment of meningitis. J. infect. Dis., 124, (suppl.), 249-253.

Newman, R. L. and Holt, R. J. (1967). Intrathecal gentamicin in treatment of ventriculitis in children. Brit. med. $J ., 2,539-542$.

Riff, L. J. and Jackson, G. G. (1971). Pharmacology of gentamicin in man. J. infect. Dis., 124, (suppl.), 98-105.

Rubenis, M., Kozij, V. M., and Jackson, G. G. (1963). Laboratory studies on gentamicin. Antimicrob. Agents Chemother., 3, 153-156.

Schoutens, E. and Yourassowsky, E. (1972). Effets du chlorure de sodium sur l'activité antistaphylococcique de la gentamicine. Path. et Biol., 20, 947-949.

Warburg, O. and Christian, W. (1942). Isolierung und Kristallisation des Gärungs Ferments Enolase. Biochem. $Z$., 310, 384-421. 